\title{
Canada Thistle (Cirsium arvense) Response to Clipping and Seeding of Competitive Grasses*
}

\author{
Julie Knudson ${ }^{1}$, Paul Meiman ${ }^{1 \#}$, Cynthia Brown ${ }^{2}$, George Beck ${ }^{2}$, Mark Paschke ${ }^{1}$, Edward Redente ${ }^{1}$ \\ ${ }^{1}$ Department of Forest and Rangeland Stewardship, Colorado State University, Colorado, USA; ${ }^{2}$ Department of Bioagricultural \\ Sciences and Pest Management, Colorado State University, Colorado, USA. \\ Email: "Paul.Meiman@ColoState.edu
}

Received July $24^{\text {th }}, 2012$; revised August $22^{\text {nd }}, 2012$; accepted August $31^{\text {st }}, 2012$

\begin{abstract}
Chemical restrictions, ecological concerns, liability issues, and public sentiment present challenges to land managers attempting to control highly invasive plants like Canada thistle (Cirsium arvense [L.] Scop.). Although herbicide application can be an effective control strategy, increasing limitations force managers of sensitive environments (e.g., national parks, wildlife refuges, protected water-bodies or waterways) to search for effective control alternatives. A greenhouse study was conducted to test the effectiveness of clipping (to simulate field mowing) and grass seeding as alternatives for Canada thistle control. Two native North American grasses (western wheatgrass [Pascopyrum smithii \{Rydb.\} A. Löve] and streambank wheatgrass [Elymus lanceolatus \{Scribn. \& J. G. Sm.\}Gould ssp. lanceolatus]) and one sterile hybrid cross between common wheat (Triticum aestivum L.) and tall wheatgrass (Thinopyrum ponticum [Podp.] Z. W. Liu \& R. C. Wang) called Regreen ${ }^{\mathrm{TM}}$ were used. The effects of clipping and grass seeding on Canada thistle growth, and the effect of Canada thistle on grass growth, were evaluated using 14 unique treatments applied to potted Canada thistle and grass plants. Clipping inhibited Canada thistle growth (by 60\%), while grass seeding had no effect. Presence of Canada thistle inhibited grass growth for all seeding treatments except when Regreen ${ }^{\mathrm{TM}}$ and western wheatgrass were seeded together with Canada thistle. Planting multiple species for restoration of Canada thistle-infested

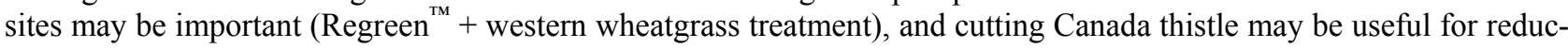
ing its growth in restored areas.
\end{abstract}

Keywords: Invasive Species; Mowing; Competition; Revegetation

\section{Introduction}

Canada thistle (Cirsium arvense L.), a highly invasive non-native perennial plant, continues to challenge land managers throughout the United States. While noxious weed legislation was first enacted against Canada thistle in Vermont in 1795 [1], truly successful Canada thistle control strategies for sensitive settings are still lacking. Herbicides such as picloram have proven quite successful in less regulated upland areas [2-5] but many areas infested with Canada thistle require an alternative control because of issues related to aquatic habitat, herbicide restrictions, threats to endangered species, liability, or human/animal-sensitivity [6-9]. These issues often occur on wildlife refuges, natural areas, state and national parks, near protected water-bodies or waterways, or on other private or public conservation lands, and create special challenges for successful weed management. The re-

\footnotetext{
*Mention of trade names and companies is solely to inform the reader and does not constitute endorsement by Colorado State University nor does it imply criticism of similar products or companies not mentioned. ${ }^{\sharp}$ Corresponding author.
}

cently released herbicide aminopyralid may be a viable alternative for managers facing herbicide restrictions because of its lower toxicity to non-target organisms [10], but additional research on this new product is necessary, and it is of little use to managers working in areas where herbicide application is prohibited.

Control methods for Canada thistle commonly used or tested in sensitive settings include hand pulling, digging, biological control, grazing, cultivation, fertilizer addition, aquatic labeled herbicides, "natural product" herbicides (e.g., acetic acid), mowing, or revegetation. Unfortunately, when used alone, most of these methods have demonstrated limited utility for significant, long-term Canada thistle reduction [11-15]. Two control measures that may be useful in combination, however, are mowing and revegetation.

Mowing is currently recommended for Canada thistle control on many weed management information websites [16-18] and is popular with landowners enrolled in the Conservation Reserve Program in the United States [19]. While the utility of strategically-timed mowing to pre- 
vent seed production is well documented [20-22], research on mowing as a standalone strategy for Canada thistle management has shown mixed results. One study found mowing conducted twice per year for 2 years temporarily decreased Canada thistle shoot density for the following 2 years, but by the third year shoot density in the mowed treatments was not different from the unmowed control [23]. Another study found that mowing three times annually for 2 years reduced Canada thistle density by $85 \%$ at a subirrigated site, but did not provide significant control at a dryland site [2]. Others report that on sites that were otherwise similar, a twice per year mowing treatment resulted in a reduction of Canada thistle density to $35 \%$ of its initial density one year later on a high density site $\left(30\right.$ shoots $\left.\cdot \mathrm{m}^{-2}\right)$, but had no effect on a lower density site (16 shoots $\left.\cdot \mathrm{m}^{-2}\right)$ [24]. Mowing an infested alfalfa (Medicago sativa L.) field twice annually produced an $86 \%$ reduction in Canada thistle density after the first year [25]. This treatment provided complete control after 4 years, demonstrating that desirable competitive plant species (e.g. alfalfa) may enhance the success of mowing. Overall however, these variable results demonstrate the need for further evaluation of mowing as part of a successful control strategy.

Revegetation has shown promise as a secondary tool for long-term control of Canada thistle following other control measures, and is becoming increasingly popular as a component of integrated weed management programs. Regardless of the target weed, a lack of competetion from desirable plants post-treatment often leads to reestablishment of unwanted weeds [26,27]. Several forbs and grasses have shown promise as effective competitors with Canada thistle, including tall fescue (Schedonorus phoenix [Scop.] Holub), crownvetch (Securigera varia [L.] Lassen), sudangrass (Sorghum bicolor [L.] Moench ssp. drummondii [Nees ex Steud.] de Wet \& Harlan), annual ragweed (Ambrosia artemisiifolia L.), common sunflower (Helianthus annuus L.), alfalfa, biennial sweetclover (Melilotus sp.), and a mixture of perennial ryegrass (Lolium perenne L.) and white clover (Trifolium repens L.) [1,28-32]. One study reported that the use of competitive grasses for Canada thistle control was as effective as herbicide application over a 3-year period [33]. Unfortunately, most plants tested thus far as competitors against Canada thistle are non-native species. While use of non-natives is understandable because they are frequently more aggressive, seeding non-native plants is often strongly discouraged or prohibited in sensitive settings. Clearly, land managers of sensitive settings face a variety of challenges when attempting Canada thistle control. The lack of effective long-term control measures combined with the lack of research specific to their needs translates into limited options for people tasked with restoring infested lands.
The following experiment was conducted to test the effectiveness of clipping (to simulate field mowing) and seeding plant species acceptable for use in sensitive settings as control measures for Canada thistle. Specifically, the objectives of this study were to: 1) determine the effects of clipping and grass competition on Canada thistle growth, 2) compare the effectiveness of the different grass seeding treatments for reducing Canada thistle growth, and 3) determine the effect of Canada thistle on the growth of each of the seeded grasses. Two North American native grasses (western wheatgrass [Pascopyrum smithii \{Rydb.\} A. Löve] and streambank wheatgrass [Elymus lanceolatus \{Scribn. \& J.G. Sm.\} Gould ssp. lanceolatus]) and one sterile commercial hybrid cross between common wheat (Triticum aestivum L.) and tall wheatgrass (Thinopyrum ponticum [Podp.] Z. W. Liu \& R. C. Wang) called Regreen ${ }^{\mathrm{TM}}$ were chosen for this research.

We hypothesized that both clipping and grass competition would reduce Canada thistle shoot biomass, and that the effect of the two factors together would be greater than either alone. We also predicted that the grass seeding treatments containing Regreen ${ }^{\mathrm{TM}}$ would reduce Canada thistle growth more than the native grasses seeded alone with Canada thistle because of the more aggressive nature of Regreen ${ }^{\mathrm{TM}}$. Additionally, we predicted that grass growth would be inhibited by the presence of Canada thistle.

\section{Materials and Methods}

A greenhouse study was conducted on potted Canada thistle plants treated with combinations of clipping (used to simulate mowing) and grass seeding. Two response variables were measured: Canada thistle shoot biomass and grass shoot biomass. Canada thistle biomass was analyzed using a two by five factorial design consisting of two levels of Canada thistle clipping (clipped, unclipped) and five levels of grass seeding (no grass, streambank wheatgrass, western wheatgrass, Regreen ${ }^{\mathrm{TM}}$, or western wheatgrass + Regreen $^{\mathrm{TM}}$ ). Grass biomass was analyzed using a three by four factorial design consisting of three levels of Canada thistle (clipped, unclipped, absent) and four levels of grass seeding (streambank wheatgrass, western wheatgrass, Regreen ${ }^{\mathrm{TM}}$, or western wheat-

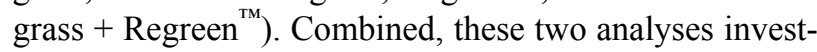
tigated a total of 14 treatment combinations applied to Canada thistle or grass plants (6 replicates per treatment) grown in potting soil for 51 weeks in a greenhouse.

\subsection{Selection of Grass Species}

Western wheatgrass and streambank wheatgrass were chosen for their aggressive underground growth habit, early spring germination prior to Canada thistle growth, 
wide geographic and habitat range throughout the western United States, drought and extreme temperature tolerance, and broad availability [34-36]. These two species have demonstrated prior success for control of other weeds including Russian knapweed (Acroptilon repens [L.] DC.) [37,38], leafy spurge (Euphorbia esula L.) [39], cheatgrass (Bromus tectorum L.), and musk thistle (Carduus nutans L.) [40,41]. Western wheatgrass has also provided effective control on sites infested with multiple weed species [42]. Most importantly, western wheatgrass has previously demonstrated some success against Canada thistle [33]. The hybrid grass Regreen ${ }^{\mathrm{TM}}$ was chosen for its ability to establish aggressive root growth more quickly than native grasses, and its sterility increases acceptability for use in sensitive settings.

\subsection{Source of Plant Material}

Western wheatgrass seed (variety "Arriba") was obtained from Pawnee Buttes Seed Inc. (Greeley, CO, USA). Streambank wheatgrass seed (variety "Sodar") was obtained from Granite Seed (Lehi, UT, USA). Regreen ${ }^{\mathrm{TM}}$ seed was obtained from Rainier Seed Company (Davenport, WA, USA). Canada thistle horizontal roots were collected from a site near Fort Collins, Colorado, USA (lat $40^{\circ} 33^{\prime} 46^{\prime \prime} \mathrm{N}$, long $105^{\circ} 00^{\prime} 24^{\prime \prime} \mathrm{W} ; 1491 \mathrm{~m}$ above sea level). Horizontal roots were collected 26 August 2004, placed in sealed plastic bags with soil collected from the same location, and transported to the laboratory in a cooler. The bagged soil was moistened and stored at $6^{\circ} \mathrm{C}$ in the dark for 8 weeks to prevent sprouting before use in the experiment. Plant nomenclature follows the USDA PLANTS Database [36].

\subsection{Plant Preparation and Treatment}

On 23 October 2004, refrigerated Canada thistle horizontal root sections were cut into $2.5-\mathrm{cm}$ long pieces (diameter ranging from 0.2 to $0.65 \mathrm{~cm}$ ) with a minimum of one bud per piece. Pieces were soaked in $2.54 \mathrm{~cm}$ of tap water in a refrigerated $\left(6^{\circ} \mathrm{C}\right)$ covered tray in the dark for $28 \mathrm{~h}$, then planted in rows at a depth of approximately $1.3 \mathrm{~cm}$ in $25-\times 52-\mathrm{cm}$ flat plastic trays filled with $2.5 \mathrm{~cm}$ of wetted Scotts MetroMix 350 potting soil (Sun Gro Horticulture, Bellevue, WA, USA). Each tray was thoroughly watered after planting and kept moist.

Germinated horizontal root pieces were transferred to $164 \mathrm{ml}$ conetainers in December 2004. In late January 2005 , the plants were transferred to $1.3-\mathrm{L}$ pots and grown for 7 weeks. Surviving plants were then transferred to 3.8-L plastic pots filled with Scotts MetroMix 350 potting soil (1 plant per pot), and grown there for the remainder of the experiment. After 10 weeks of postemergence growth, 12 grass seeds were added to 48 of the 60 Canada thistle pots (Canada thistle control pots had no seeded grasses). Each pot assigned to a grass seeding treatment received 12 grass seeds (six of each species for the two-species treatment). Western wheatgrass and streambank wheatgrass seeds were planted approximately 1.3 $\mathrm{cm}$ deep, while Regreen ${ }^{\mathrm{TM}}$ seeds were planted approximately $0.6 \mathrm{~cm}$ deep. More seeds were planted than needed to assure establishment of a sufficient number of plants. Twenty four grass control pots of the same size and growth medium as the Canada thistle pots were seeded with only grasses as described above. The result was six replicate pots for each treatment combination.

Six weeks after initial seeding, adequate grass seed germination was obtained and pots were thinned to four grass plants per pot. Regreen ${ }^{\text {TM }}+$ western wheatgrass $^{-1}$ treatments were thinned to two grass plants per species in each pot. Because of limited project resources, only one grass species combination treatment was evaluated. Western wheatgrass was chosen for this combination with Regreen ${ }^{\mathrm{TM}}$ because of its more aggressive rhizometous growth habit than streambank wheatgrass [34]. At 17 weeks of Canada thistle growth when plants were blooming, the single clipping treatment was performed, cutting plants with hand shears $9 \mathrm{~cm}$ above the soil surface to simulate mowing. This clipping height was chosen because it is the approximate mowing height used in field studies for mowing Canada thistle [2,43]. Clipped shoot biomass from each Canada thistle plant was placed in individual paper bags, dried at $55^{\circ} \mathrm{C}$ to constant mass and weighed to determine Canada thistle shoot biomass. Grasses were not clipped.

Experimental plants grew in the greenhouse for an additional 34 weeks post-clipping at approximately $22^{\circ} \mathrm{C} \pm$ $5^{\circ} \mathrm{C}$, and were watered as needed and weeded for nonexperimental species. Plants received natural light supplemented with $400-\mathrm{W}$ high pressure sodium vapor bulbs (1.5 $\mathrm{m}$ above greenhouse benches) to obtain a 16-h photoperiod. Pot locations on the greenhouse bench were re-randomized and pots were moved every 6 weeks to minimize effects of potential differences in light or temperature. For the final harvest, experimental plants were clipped at the soil surface and separated into grass shoot biomass or Canada thistle shoot biomass for each pot and placed in separate paper bags. It was not possible to accurately separate root biomass when multiple species grew in the same pot, thus root biomass was not considered further. Plant material was dried at $55^{\circ} \mathrm{C}$ to constant mass and weighed to determine shoot biomass for each plant species.

\subsection{Statistical Analyses}

Two dependent variables were analyzed: Canada thistle shoot biomass and grass shoot biomass. Canada thistle biomass was analyzed using a two by five factorial de- 
sign consisting of two levels of Canada thistle clipping (clipped, unclipped) and five levels of grass seeding (no grass, streambank wheatgrass, western wheatgrass, Regreen $^{\mathrm{TM}}$, or western wheatgrass + Regreen $^{\mathrm{TM}}$ ). Grass biomass was analyzed with a three by four factorial design consisting of three levels of Canada thistle (clipped, unclipped, absent) and four levels of grass seeding (streambank wheatgrass, western wheatgrass, Regreen ${ }^{\mathrm{TM}}$, or western wheatgrass + Regreen $^{\mathrm{TM}}$ ). The data were analyzed using two separate univariate two-way analyses of variance (ANOVA); one for each dependent variable. Canada thistle shoot biomass and grass shoot biomass data were natural log transformed to meet assumptions of the analyses. Post hoc pair-wise comparisons of interest were conducted using Tukey's Honestly Significant Difference (HSD). All data were analyzed using R 2.8.1 statistical software [44] and an alpha level of 0.05 .

\section{Results}

Clipping reduced Canada thistle shoot biomass $\left(\mathrm{F}_{1,50}=\right.$ 126.54, $P<0.001)$. Mean shoot biomass of Canada thistle in the clipped treatments $(3.12 \pm 0.20 \mathrm{~g}$ [mean $\pm \mathrm{SE}$ ], $\mathrm{n}=30$ ) was lower than the unclipped Canada thistle treatments $(8.02 \pm 0.41 \mathrm{~g}, \mathrm{n}=30)$, regardless of the presence of grass or species seeded. Clipped plants produced less than half the shoot biomass of their unclipped counterparts, despite having 34 weeks for regrowth. Grass seeding did not affect shoot biomass of Canada thistle $\left(\mathrm{F}_{4,50}=0.78, P=0.544\right)$, and there was no interaction between clipping and grass seeding on Canada thistle shoot biomass $\left(\mathrm{F}_{4,50}=0.85, P=0.500\right)$.

Grass shoot biomass was affected by the presence and clipping status of Canada thistle $\left(\mathrm{F}_{2,56}=43.47, P<0.001\right)$, and varied by grass species seeded $\left(\mathrm{F}_{3,56}=37.35, P<\right.$ 0.001 ), as indicated by the interaction between Canada thistle treatment and grass species seeded $\left(\mathrm{F}_{6,56}=2.38, P\right.$ $=0.040)$. The presence of unclipped Canada thistle reduced grass shoot biomass below that of the control (Canada thistle absent) when grasses were grown individually regardless of species (Figure 1). When grass species were paired (Regreen ${ }^{\mathrm{TM}}+$ western wheatgrass), however, the presence of unclipped Canada thistle did not significantly reduce grass shoot biomass.

Western wheatgrass was the only grass treatment that produced more grass shoot biomass when grown in the absence of Canada thistle than when grown with clipped Canada thistle ( $P=0.024$, Figure 1). Streambank wheatgrass $(P=0.124)$, Regreen ${ }^{\mathrm{TM}}(P=0.231)$, and the grass combination $^{(\text {Regreen }}{ }^{\text {TM }}+$ western wheatgrass $)(P=$ 0.999) produced similar amounts of shoot biomass regardless of whether grown in the absence of Canada thistle or with clipped Canada thistle.

The two most successful grass treatments overall in

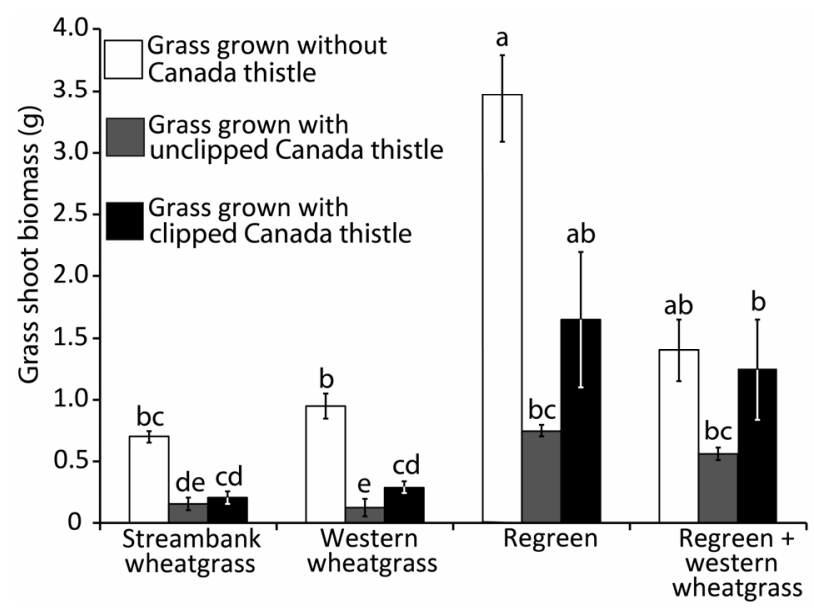

Figure 1. Mean grass shoot biomass by treatment for grass species grown in the presence or absence of Canada thistle (Cirsium arvense [L.] Scop.). Means ( \pm SE, $n=6$ except for one treatment group where one outlier was eliminated) with letters in common across all grass species and treatments are not significantly different using Tukey's HSD $(\alpha=0.05)$.

terms of shoot biomass produced were Regreen ${ }^{\mathrm{TM}}$, and Regreen $^{\mathrm{TM}}+$ western wheatgrass. Regreen ${ }^{\mathrm{TM}}+$ western wheatgrass was the only grass treatment where the presence of unclipped Canada thistle did not produce a detectable effect $(P=0.404)$. In fact, Regreen ${ }^{\mathrm{TM}}+$ western wheatgrass was the only grass treatment where no detectable difference in shoot biomass was found regardless of Canada thistle presence or clipping status (Figure 1). All other grass treatments (including western wheatgrass and Regreen ${ }^{\mathrm{TM}}$ grown separately) produced less shoot biomass in the presence of Canada thistle, at least in its unclipped state.

\section{Discussion}

\subsection{Canada Thistle Response to Clipping}

The significant reduction in aboveground Canada thistle biomass as a result of clipping, despite adequate time for regrowth, confirms our hypothesis that clipping reduces Canada thistle shoot biomass and supports the potential utility of mechanical cutting as a control measure for Canada thistle. Similar results have been demonstrated in field studies. One study reported field mowing reduced Canada thistle growth by $85 \%$ [2], while another reported a $95 \%$ reduction in Canada thistle growth after 2 years of field mowing [45]. In some cases, mowing has virtually eliminated Canada thistle after 4 years [46].

Conversely, others have found that a one-time field mowing treatment did not affect shoot biomass in the year of treatment or 2 years later [47]. In a German study similar to ours, a 2-year field experiment was conducted where potted Canada thistle plants were clipped once annually to simulate mowing [48]. The first year, clip- 
ping resulted in an increase in Canada thistle shoot biomass compared to the unclipped control. It was only in the second year that the clipped Canada thistle plants responded in a manner similar to our study, where clipped plants produced less shoot biomass than unclipped controls.

One difference between the German study and ours was the height of clipping. Clipping height was $30 \mathrm{~cm}$ in their study [48], leaving a significant amount of photosynthesizing foliage behind, which likely facilitated first year regrowth. Those authors theorized that their mild clipping treatment mimicked moderate herbivory, where plant growth would be stimulated by removal of top growth. In our study, Canada thistle was clipped at a standard mowing height of $9 \mathrm{~cm}$, leaving little foliage behind. This more substantial removal of plant material likely inhibited regrowth by reducing photosynthetic carbohydrate production. Removal of plant top-growth through activities such as mowing is believed to weaken Canada thistle plants by inhibiting photosynthetic carbohydrate production and transport, while also forcing depletion of root carbohydrate reserves to support regrowth after cutting [49]. This may explain the inability of the clipped plants to fully recover after the second clipping in the German study [48].

Another difference between the German study and ours was the timing of clipping. Root carbohydrate reserves of Canada thistle are considered to be lowest at the initiation of flowering [46,50]. In our study, Canada thistle was clipped when $99 \%$ of the plants were flowering. Clipping our plants when carbohydrate reserves were low may have enhanced the effectiveness of our clipping treatment. In the German study, plants were clipped in June each year, before flowering [48]. In their study, flowering occurred later in the growing season, with only $6 \%$ of control heads beginning to flower by August the first year, and $43 \%$ of control heads beginning to flower by August the second year [48]. With earlier flowering the second year, root carbohydrate reserves may have been lower at the time of clipping than the first year, perhaps also contributing to the decrease in biomass of clipped plants the second year. It may be that height of clipping and timing of clipping relative to flowering play a critical role in the relative success of clipping treatments for control of Canada thistle.

\subsection{Canada Thistle Response to Grass Seeding}

Although the presence of grass plants did not inhibit Canada thistle shoot growth in this study (contrary to the hypothesis), the effect of the grasses on Canada thistle root growth was not assessed. A key requirement for grass species selection in this study was an aggressive underground growth habit. Native grasses such as alkali sacaton (Sporobolus airoides [Torr.] Torr.) have been shown in greenhouse studies to inhibit Canada thistle root growth while demonstrating no effect on Canada thistle shoot biomass [51]. A 1-yr greenhouse experiment may be too short for root competition to result in changes in aboveground Canada thistle biomass. Canada thistle shoot biomass fluctuated significantly for the first 2 years of a field study when grown in the presence of plant competitors, and those authors concluded that plant competitors require more than two seasons of growth before they can effectively suppress Canada thistle [28]. Conversely, others report that seeding the competitive exotic grasses perennial ryegrass (Lolium perenne L.), Italian ryegrass (Lolium perenne L. ssp. multiflorum [Lam.] Husnot), and orchardgrass reduced shoot biomass of potted Canada thistle plants each year of their 2-year study [52].

The grasses for this experiment were also selected for their drought tolerance, a benefit untested under greenhouse conditions, but potentially important under hot, dry field conditions. For example, western wheatgrass establishes and maintains cover across a range of soil moisture availabilities [53], while Canada thistle growth may be suppressed when soil moisture availability is reduced [54]. Hot, dry years may allow grasses such as western wheatgrass to gain a foothold over Canada thistle under field conditions.

\subsection{Canada Thistle Response to Grass Seeding $\times$ Clipping}

Contrary to our hypothesis that the combined effect of clipping and grass competition on Canada thistle biomass would be greater than either factor alone, there was no synergistic effect of clipping and grass seeding in our study, although different results may be expected in field trials. One field study demonstrated that seeding perennial grasses and mowing twice annually for 3 years can reduce Canada thistle density by more than $90 \%$ [33]. Other testing of grass seeding and field mowing for control of Canada thistle has found that while the competetive ability of the grasses was important for controlling Canada thistle in the early stages of the experiment, as the age of the grass stand increased and mowing continued, the effects of mowing became more important than competition between the grass and Canada thistle [22].

\subsection{Grass Response to Canada Thistle Presence and Species of Grass Seeded}

The negative effect of unclipped Canada thistle on shoot biomass of each of the single-species grass treatments in our study was hypothesized and expected because previous researchers have demonstrated the negative impacts Canada thistle can have on the growth of other plants [55-57]. What was surprising in our study was the 
failure of Canada thistle to reduce shoot biomass of the

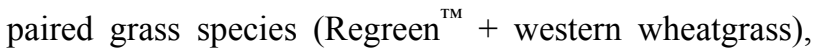
regardless of Canada thistle clipping status. The mechanism driving the resilience of the paired grass treatment is unclear, but one likely explanation is the increased functional group diversity $[58,59]$ resulting from the presence of an annual and a perennial grass. Another possibility, although more difficult to substantiate, is the cumulative effect of allelochemicals produced by both Regreen $^{\mathrm{TM}}$ and western wheatgrass. Common wheat (one of the hybrid components of Regreen ${ }^{\mathrm{TM}}$ ) is believed to have allelopathic potential against weeds in cropping systems [60], and there is some evidence of phytotoxic allelochemical production by western wheatgrass $[61,62]$.

This study also elucidated the potential utility of mechanical cutting of Canada thistle to enhance grass growth when only a single desirable species is seeded. While shoot biomass growth of all of the single grass species was inhibited by the presence of unclipped Canada thistle, clipping Canada thistle resulted in greater grass biomass for each single species treatment equivalent to grass biomass in the complete absence of Canada thistle (with the exception of western wheatgrass). Grass growth may benefit from Canada thistle cutting not only because of the weakened state of the Canada thistle plants, but also from the decrease in competitive plant canopy.

The lack of benefit to western wheatgrass from Canada thistle clipping may be a product of short study duration. Regreen ${ }^{\mathrm{TM}}$ establishes and produces growth more quickly than many species considered for revegetation [63]. Streambank wheatgrass also establishes and matures more quickly than western wheatgrass [34]. It may take longer for the benefits of Canada thistle clipping to translate into increased growth of western wheatgrass.

While the seeded grasses did not significantly inhibit Canada thistle shoot biomass in this study, it is probable that a field study, performed over a longer duration, would more clearly determine the utility of these grasses for restoration of Canada thistle infested sites. The aggressive underground growth of these grasses may not translate to observable aboveground effects on Canada thistle for several seasons (regardless of additional control measures used), and the characteristics of these grasses for which they were initially chosen (such as drought tolerance and early season germination) may translate to further advantages over Canada thistle in a field setting.

The results of this experiment demonstrate the potential for both mechanical cutting and grass seeding as effective tools for restoration of Canada thistle infested sites. The one-time clipping event resulted in a decrease in Canada thistle biomass, and has implications for the use of mowing as a field control measure. As revegetation tools, the grasses used in this experiment proved to be tolerant of Canada thistle presence, and the combination of Regreen ${ }^{\mathrm{TM}}$ and western wheatgrass demonstrated the ability to grow equally well regardless of Canada thistle presence or cutting status. This is an important finding, as it is generally considered that almost any control measure for Canada thistle requires multiple applications, with complete eradication impossible or at least requiring multiple seasons. Thus any useful revegetation species must be capable of growing in concert with Canada thistle until it can be controlled. The success of this combination grass seeding also emphasizes the potential importance of the synergistic effects of using more than one species for restoration of Canada thistle infested sites.

\section{Acknowledgements}

We thank the Colorado Agricultural Experiment Station, (Dr. Lee Sommers, Director) and Colorado State University, Fort Collins, CO, USA for funding this experiment. We also thank Dr. Phil Westra, Dr. Paul Duffy, and Lonnie Pilkington for their assistance and contributions to this project, as well as Rainier Seed Company and Granite Seed Company for donating grass seed.

\section{REFERENCES}

[1] F. Detmers, "Canada Thistle (Cirsium arvense Tourn.), Field Thistle, Creeping Thistle," Technical Bulletin 414, University of Ohio Agricultural Experiment Station, Columbus, 1927.

[2] K. G. Beck and J. Sebastian, "Combining Mowing and Fall-Applied Herbicides to Control Canada Thistle (Cirsium arvense)," Weed Technology, Vol. 14, No. 2, 2000, pp. 351-356. doi:10.1614/0890-037X(2000)014[0351:CMAFAH]2.0.C $\underline{\mathrm{O} ; 2}$

[3] W. W. Donald, "Retreatment with Fall-Applied Herbicides for Canada Thistle (Cirsium arvense) Control," Weed Science, Vol. 41, No. 3, 1993, pp. 434-440.

[4] L. E. Foote, D. L. Kill and C. S. Williams, "Canada Thistle Control on Roadsides," Weed Science, Vol. 18, No. 2, 1970, pp. 307-310.

[5] S. C. Peterson and J. V. Parochetti, "Canada Thistle (Cirsium arvense) Control in Timothy (Phleum pratense) and Red Clover (Trifolium pretense) Sward," Weed Science, Vol. 26, 1978, pp. 215-220.

[6] J. Krueger-Mangold, R. L. Sheley and B. D. Roos, "Maintaining Plant Community Diversity in a Waterfowl Production Area by Controlling Canada Thistle (Cirsium arvense) Using Glyphosate," Weed Technology, Vol. 16, No. 2, 2002, pp. 457-463. doi:10.1614/0890-037X(2002)016[0457:MPCDIA]2.0.C $\underline{\mathrm{O} ; 2}$

[7] R. G. Lym and C. G. Messersmith, "Survey for Picloram in North Dakota Groundwater," Weed Technology, Vol. 2, No. 2, 1988, pp. 217-222. 
[8] K. M. Norgaard, "The Politics of Invasive Weed Management: Gender, Race and Risk Perception in Rural California," Rural Sociology, Vol. 72, No. 3, 2007, pp. 450-477. doi:10.1526/003601107781799263

[9] US Environmental Protection Agency, "Endangered Species Protection Bulletin," 2011.

http://www.epa.gov/oppfead1/endanger/bulletins.htm

[10] US Environmental Protection Agency, “Aminopyralid Pesticide Fact Sheet," Office of Pesticide Programs, Arlington, 2005.

[11] J. Jacobs, J. Sciegienka and F. Menalled, "Ecology and Management of Canada Thistle [Cirsium arvense (L.) Scop.]," Invasive Species Technical Note MT-5, Natural Resource Conservation Service, US Department of Agriculture, Bozeman, 2006.

[12] J. Radhakrishnan, J. R. Teasdale and C. B. Coffman, "Agricultural Applications of Vinegar," Proceedings of the 57th Annual Northeastern Weed Science Society Meeting, Baltimore, 6-9 January 2003, p. 63.

[13] P. E. Reece and R. G. Wilson, "Effect of Canada Thistle (Cirsium arvense) and Musk Thistle (Carduus nutans) Control on Grass Herbage," Weed Science, Vol. 31, No. 4, 1983, pp. 488-492.

[14] C. C. Reed, D. L. Larson and J. L. Larson, "Canada Thistle Biological Control Agents on Two South Dakota Wildlife Refuges," Natural Areas Journal, Vol. 26, No. 1, 2006, pp. 47-52. doi:10.3375/0885-8608(2006)26[47:CTBCAO]2.0.CO;2

[15] R. L. Zimdahl and G. Foster, "Canada Thistle (Cirsium arvense) Control with Disking and Herbicides," Weed Technology, Vol. 7, No. 1, 1993, pp. 146-149.

[16] Plant Conservation Alliance, "Canada Thistle," 2011. http://www.nps.gov/plants/ALIEN/fact/ciar1.htm

[17] US Army Corps of Engineers, "Canada Thistle (Cirsium arvense) Mechanical Control,” 2009.

http://el.erdc.usace.army.mil/emrrp/emris/emrishelp4b/mo wing_canada_thistle.htm

[18] Wisconsin Department of Natural Resources, "Canada Thistle," 2004.

http://dnr.wi.gov/invasives/fact/canada_thistle.htm

[19] C. Holen, H. Person, B. Holder, R. Severson and M. Halstvedt, "Canada Thistle Control on Conservation Reserve Program Land," In: H. Kandel, R. Severson and P. Glogoza, Eds., Report: 2006 On-Farm Cropping Trials Northwest and West Central Minnesota, Crookston, 2007, pp. 35-36.

[20] L. A. Derscheid and R. E. Schultz, "Achene Development of Canada Thistle and Perennial Sowthistle," Weeds, Vol. 8, No. 1, 1960, pp. 55-62. doi:10.2307/4040507

[21] R. J. Moore, "The Biology of Canadian Weeds. 13. Cirsium arvense (L.) Scop.," Canadian Journal of Plant Science, Vol. 55, No. 4, 1975, pp. 1033-1048. doi: $10.4141 /$ cjps $75-163$

[22] F. P. Thrasher, C. S. Cooper and J. M. Hodgson, "Competition of Forage Species with Canada Thistle, as Affected by Irrigation and Nitrogen Levels," Weeds, Vol. 11, No. 2, 1963, pp. 136-138. doi:10.2307/4040707

[23] R. F. Pywell, M. J. Hayes, J. B. Tallowin, K. J. Walker,
W. R. Meek, C. Carvell, L. A. Warman and J. M. Bullock, "Minimizing Environmental Impacts of Grassland Weed Management: Can Cirsium arvense Be Controlled without Herbicides?" Grass and Forage Science, Vol. 65, No. 2, 2010, pp. 159-174. doi:10.1111/j.1365-2494.2010.00735.x

[24] A. J. Bicksler and J. B. Masiunas, "Canada Thistle (Cirsium arvense) Suppression with Buckwheat or Sudangrass Cover Crops and Mowing," Weed Technology, Vol. 23, No. 4, 2009, pp. 556-563. doi:10.1614/WT-09-050.1

[25] J. M. Hodgson, "The Nature, Ecology and Control of Canada Thistle," Technical Bulletin 1386, US Department of Agriculture, Washington DC, 1968.

[26] R. L. Sheley and M. F. Carpinelli, "Creating Weed-Resistant Plant Communities Using Niche-Differentiated Nonnative Species," Rangeland Ecology \& Management, Vol. 58, No. 5, 2005, pp. 480-488. doi:10.2111/03-142.1

[27] A. J. Travnicek, R. G. Lym and C. Prosser, "Fall-Prescribed Burn and Spring-Applied Herbicide Effects on Canada Thistle Control and Soil Seedbank in a Northern Mixed-Grass Prairie," Rangeland Ecology \& Management, Vol. 58, No. 4, 2005, pp. 413-422. doi:10.2111/1551-5028(2005)058[0413:FBASHE]2.0.CO ;2

[28] B. N. Ang, L. T. Kok, G. I. Holtzman and D. D. Wolf, "Competitive Growth of Canada Thistle, Tall Fescue, and Crownvetch in the Presence of a Thistle Defoliator, Cassida rubiginosa Muller (Coleoptera: Chrysomelidae)," Biological Control, Vol. 4, No. 3, 1994, pp. 277-284. doi:10.1006/bcon.1994.1035

[29] A. J. Bicksler, "Canada Thistle Management Systems for Sustainable and Organic Farms," Ph.D. Dissertation, University of Illinois at Urbana-Champaign, Urbana, 2009.

[30] M. G. Cripps, G. R. Edwards, G. W. Bourdot, D. J. Saville, H. L. Hinz and S. V. Fowler, "Effects of Pasture Competition and Specialist Herbivory on the Performance of Cirsium arvense," Biocontrol Science and Technology, Vol. 20, No. 6, 2010, pp. 641-656. doi:10.1080/09583151003695407

[31] P. D. Ominski, M. H. Entz and N. Kenkel, "Weed Suppression by Medicago sativa in Subsequent Cereal Crops: A Comparative Survey," Weed Science, Vol. 47, No. 3, 1999, pp. 282-290.

[32] L. G. Perry, S. A. Cronin and M. W. Paschke, "Native Cover Crops Suppress Exotic Annuals and Favor Native Perennials in a Greenhouse Competition Experiment," Plant Ecology, Vol. 204, No. 2, 2009, pp. 247-259. doi:10.1007/s11258-009-9588-1

[33] R. G. Wilson and S. D. Kachman, "Effect of Perennial Grasses on Canada Thistle (Cirsium arvense) Control," Weed Technology, Vol. 13, No. 1, 1999, pp. 83-87.

[34] D. Ogle, "Western Wheatgrass Plant Guide," Idaho State Office, Natural Resource Conservation Service, US Department of Agriculture, Washington DC, 2000.

[35] D. Ogle, "Streambank Wheatgrass Plant Guide," Idaho State Office, Natural Resource Conservation Service, US Department of Agriculture, Washington DC, 2006.

[36] US Department of Agriculture, "The PLANTS Database," 2009. http://plants.usda.gov 
[37] L. J. Benz, K. G. Beck, T. D. Whitson and D. W. Koch, "Reclaiming Russian Knapweed Infested Rangeland," Journal of Range Management, Vol. 52, No. 4, 1999, pp. 351-356. doi: $10.2307 / 4003545$

[38] R. M. Bottoms and T. D. Whitson, "A Systems Approach for the Management of Russian Knapweed (Centaurea repens)," Weed Technology, Vol. 12, No. 2, 1998, pp. 363-366.

[39] R. G. Lym, "The Biology and Integrated Management of Leafy Spurge (Euphorbia esula) on North Dakota Rangeland," Weed Technology, Vol. 12, No. 2, 1998, pp. 367373.

[40] K. K. Rose, A. L. Hild, T. D. Whitson, D. W. Koch and L. Van Tassell, "Competitive Effects of Cool-Season Grasses on Reestablishment of Three Weed Species," Weed Technology, Vol. 15, No. 4, 2001, pp. 885-891. doi:10.1614/0890-037X(2001)015[0885:CEOCSG]2.0.C $\underline{\mathrm{O} ; 2}$

[41] T. D. Whitson and D. W. Koch, "Control of Downy Brome (Bromus tectorum) with Herbicides and Perennial Grass Competition," Weed Technology, Vol. 12, No. 2, 1998, pp. 391-396.

[42] R. G. Wilson, S. B. Orloff, D. L. Lancaster, D. W. Kirby and H. L. Carlson, "Integrating Herbicide Use and Perennial Grass Revegetation to Suppress Weeds in Noncrop Areas," Invasive Plant Science and Management, Vol. 3, No. 1, 2010, pp. 81-92. doi:10.1614/IPSM-09-008.1

[43] K. G. Beck and J. Sebastian, "An Integrated Canada Thistle Management System Combining Mowing with FallApplied Herbicides," Proceedings of the 46th Annual Western Society of Weed Science Meeting, Tucson, 9-11 March 1993, pp. 102-104.

[44] R Development Core Team, "R: A language and Environment for Statistical Computing," R Foundation for Statistical Computing, Vienna, 2009.

[45] R. L. Amor and R. V. Harris, "Control of Cirsium arvense (L.) Scop. by Herbicides and Mowing," Weed Research, Vol. 17, No. 5, 1977, pp. 303-309. doi:10.1111/j.1365-3180.1977.tb00483.x

[46] F. A. Welton, V. H. Morris and A. J. Hartzler, "Organic Food Reserves in Relation to the Eradication of Canada Thistles," Technical Bulletin 441, University of Ohio Agricultural Experiment Station, Columbus, 1929.

[47] C. W. Grekul and E. W. Bork, "Fertilization Augments Canada Thistle (Cirsium arvense L. Scop) Control in Temperate Pastures with Herbicides," Crop Protection, Vol. 26, No. 4, 2007, pp. 668-676. doi:10.1016/i.cropro.2006.06.005

[48] S. Kluth, A. Kruess and T. Tscharntke, "Influence of Mechanical Cutting and Pathogen Application on the Performance and Nutrient Storage of Cirsium arvense," Journal of Applied Ecology, Vol. 40, No. 2, 2003, pp. 334-343. doi:10.1046/j.1365-2664.2003.00807.x

[49] C. M. Boerboom and D. L. Wyse, "Response of Canada Thistle (Cirsium arvense) and Birdsfoot Trefoil (Lotus corniculatus) to Bentazon," Weed Science, Vol. 36, No. 2, 1988, pp. 250-253.
[50] A. C. Arny, "Variations in the Organic Reserves in Underground Parts of Five Perennial Weeds from Late April to November," Technical Bulletin 84, University of Minnesota Agricultural Experiment Station, St Paul, 1932.

[51] A. Ferrero-Serrano, T. R. Collier, A. L. Hild, B. A. Mealor and T. Smith, "Combined Impacts of Native Grass Competition and Introduced Weevil Herbivory on Canada Thistle (Cirsium arvense)," Rangeland Ecology \& Management, Vol. 61, No. 5, 2008, pp. 529-534. doi:10.2111/07-142R.1

[52] J. Friedli and S. Bacher, "Direct and Indirect Effects of a Shoot-Base Boring Weevil and Plant Competition on the Performance of Creeping Thistle, Cirsium arvense," Biological Control, Vol. 22, No. 3, 2001, pp. 219-226. doi:10.1006/bcon.2001.0971

[53] L. M. Laurialt, R. E. Kirksey and D. M. VanLeeuwen, "Performance of Perennial Cool-Season Forage Grasses in Diverse Soil Moisture Environments, Southern High Plains, USA," Crop Science, Vol. 45, No. 3, 2005, pp. 909-915. doi:10.2135/cropsci2004.0280

[54] W. W. Donald and T. Prato, "Efficacy and Economics of Herbicides for Canada Thistle (Cirsium arvense) Control in No-Till Spring Wheat (Triticum aestivum)," Weed Science, Vol. 40, No. 2, 1992, pp. 233-240.

[55] G. M. Bendall, "The Allelopathic Activity of Californian Thistle (Cirsium arvense (L.) Scop.) in Tasmania," Weed Research, Vol. 15, No. 2, 1975, pp. 77-81. doi:10.1111/j.1365-3180.1975.tb01102.x

[56] W. J. Stachon and R. L. Zimdahl, "Allelopathic Activity of Canada Thistle (Cirsium arvense) in Colorado," Weed Science, Vol. 28, No. 1, 1980, pp. 83-86.

[57] R. G. Wilson, "Effect of Canada Thistle (Cirsium arvense) Residue on Growth of Some Crops," Weed Science, Vol. 29, No. 2, 1981, pp. 159-164.

[58] M. L. Pokorny, R. L. Sheley, C. A. Zabinski, R. E. Engel, T. J. Svejcar and J. J. Borkowski, "Plant Functional Group Diversity as a Mechanism for Invasion Resistance," Restoration Ecology, Vol. 13, No. 3, 2005, pp. 448-459. doi:10.1111/j.1526-100X.2005.00056.X

[59] J. L. Funk, E. E. Cleland, K. N. Suding and E. S. Zavaleta, "Restoration Through Reassembly: Plant Traits and Invasion Resistance," Trends in Ecology and Evolution, Vol. 23, No. 12 , 2008, pp. 695-703. doi:10.1016/j.tree.2008.07.013

[60] Y. Ma, "Allelopathic Studies of Common Wheat (Triticum aestivum L.)," Weed Biology and Management, Vol. 5, No. 3, 2005, pp. 93-104. doi:10.1111/j.1445-6664.2005.00164.x

[61] U. G. Bokhari, "Allelopathy among Prairie Grasses and Its Possible Ecological Significance," Annals of Botany, Vol. 42, No. 1, 1978, pp. 127-136.

[62] R. K. Kohli, H. P. Singh and D. R. Batish, "Allelopathy in Agroecosystems," Haworth Press, New York, 2001.

[63] D. Glen, "Regreen: A Cool Season, Soil Stabilizing Cover Crop,” HybriTech Seed International, Inc., Wichita, 1992. 